\title{
INJURIES ASSOCIATED WITH FIREWORKS - A REAL THREAT AMONG CHILDREN POPULATION
}

\section{Florin Daniel Enache ${ }^{1}$, Daniel Ovidiu Costea ${ }^{1}$}

\begin{abstract}
People use fireworks to celebrate religious and other holidays in many countries around the world. Fireworks have been banned in a lot of countries but still pose a high potential risk of injuries, especially among male children. Hands and fingers sustain the largest number of injuries followed by legs, then eye injuries. In addition, the lesions from fireworks can be "life-changing" if it occurs on someone's dominant hand, which may never regain its original function if the injury is very severe, or if it produces loss of vision.
\end{abstract}

Keywords: Fireworks, Injuries, Children, Legislation, Prevention

\section{Introduction}

Fireworks are devices with origin in ancient China and they contain combustible chemicals that cause explosives [1], bright and colorful effects. They contain sulfur, charcoal and gunpowder, and the red-hot fragments can reach more than 1,300 degrees, according to the CPSC (Consumer Product Safety Commission in the USA). They are used in many countries around the world to celebrate different festive occasions related to reiligious traditions, historical or cultural events. Examples include Independence Day in the United States, Guy Fawkes' night in Australia, Britain and New Zealand, Deewali in India, New Year in China and Italy, Prophet's birthday in Libya and Hari Raya festival in Malaysia [2]. In Romania, fireworks pose serious problems during Christmas or Easter Holiday and New Year's Eve.

\section{Purpose}

Children are in high risk of injury from fireworks and represent more than $30 \%$ of emergency room visits for fireworks-related injuries. Children between the ages of 5 and 9 years are more than twice as likely as people in other age groups to be injured by fireworks [3]. Other studies say that adolescents, especially boys are more affected. Boys' injuries are usually self inflected, while injured girls are usually bystanders [4].

In Romania there are no studies with reference to fireworks. The legislation has existed since 1995, but illegal sales and imports increase especially during the Christian holidays and the end of the year, when unsupervised children are victims of these devices. We want to describe as an example the case of an adolescent boy admmited in the Clinic last year arround Christmas Eve with a hand injury after a firework explosion while holding the device. As a complement to the lesional framework, we wanted to describe the legislative state and to present certain safety rules in handling these devices.

\section{Material and method}

The case that we wanted to present is an 11 year old boy who came in the Emergency Room and then was admitted in our Department for write hand lesions after a firework explosion while holding it in his hand. He had severe blast lesions in his palm and of his thumb, with nail loss. The soft tissue of the first phalanx of the index, including the nail, were amputated, exposing the bone (figg. $1-4)$.

He went immediately in the operating room, where, under general anesthesia we've done an amputation of the first phanlanx of the index and also of the distal interphalangian joint. The remaining soft tissue was used to close the amputation site. After repeated dressing every 24 and then $48 \mathrm{~h}$, in 4 weeks the result is shown in figg. 5-7.

\section{Results}

The end result in this case was a good one, without serious injuries that can lead to a severe functional disability, such as blindness or amputation of important parts of the hand or even the entire hand. This boy will manage to use the right hand with no difficulty, even for writting.

Such cases, as an example, must lead the authorities to get more seriously involved in the problem of fireworks and all so-called explosive entertainment devices that can cause severe injuries, if handled by unauthorized persons, especially children, and in inappropriate environments.

Romanian law divides firework devices in 4 classes [5]. Objects from first class can be selled all year long, second class only between 27th -31 th of December and can be used only on the 31 st of December and 1st of January. Pyrotechnic devices in classes III and IV may be handed over and put into use only to persons authorized as pyrotechnicians.

For the organization of fireworks with pyrotechnic objects from the 3rd and 4th classes, the approval of the county police inspectorate, respectively of the General Police Department of Bucharest is required. Fireworks with pyrotechnic objects from the 4th grade can be performed only by specialized persons, authorized by law, with all measures taken to prevent fires.

${ }^{1}$ Faculty of Medicine, Ovidius University of Constanţa

E-mail: dr.enache@chirurgiecopii.ro,danielocostea@gmail.com 


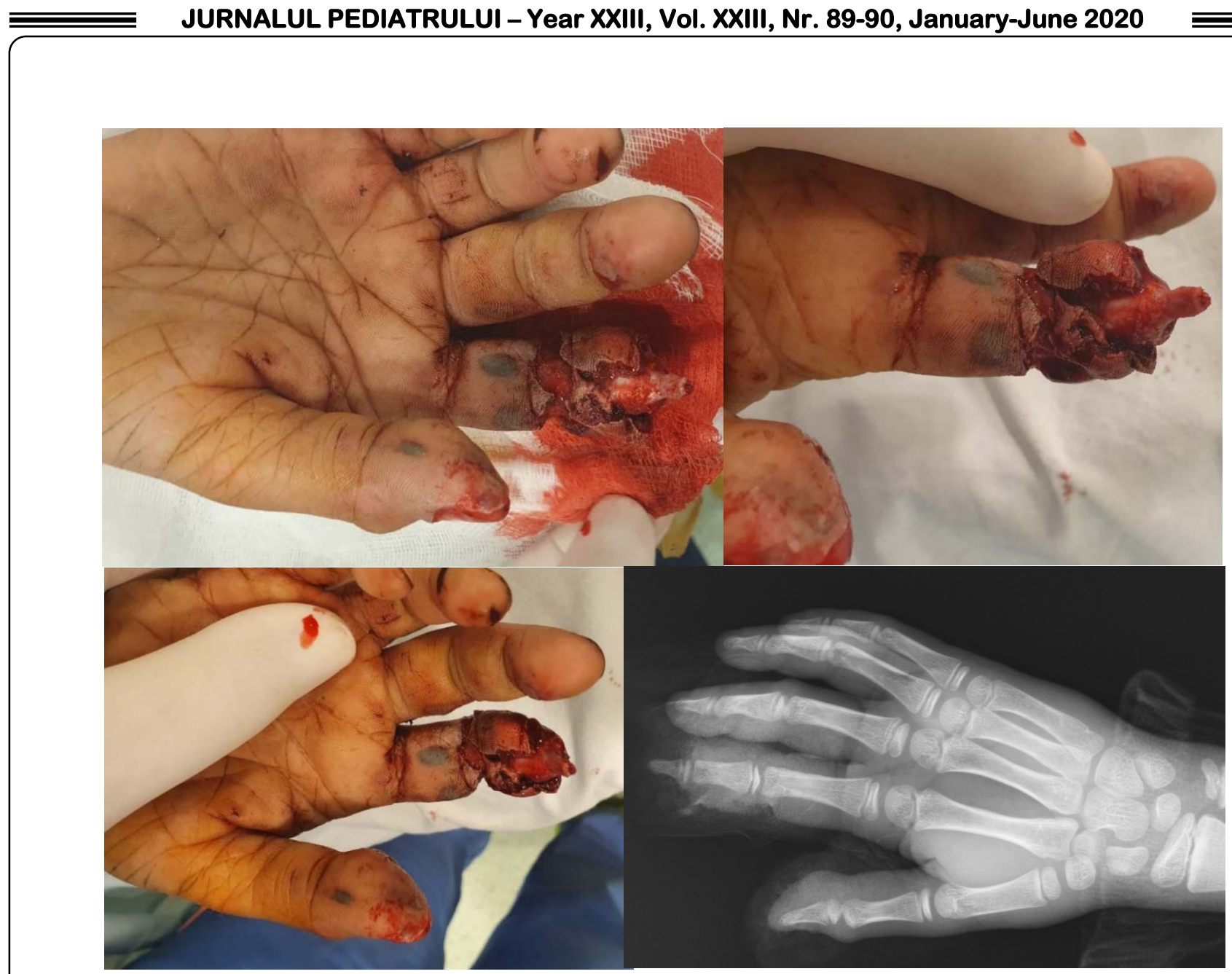

Fig. 1-4.The aspect of the right hand after firework explosion, including the Xray

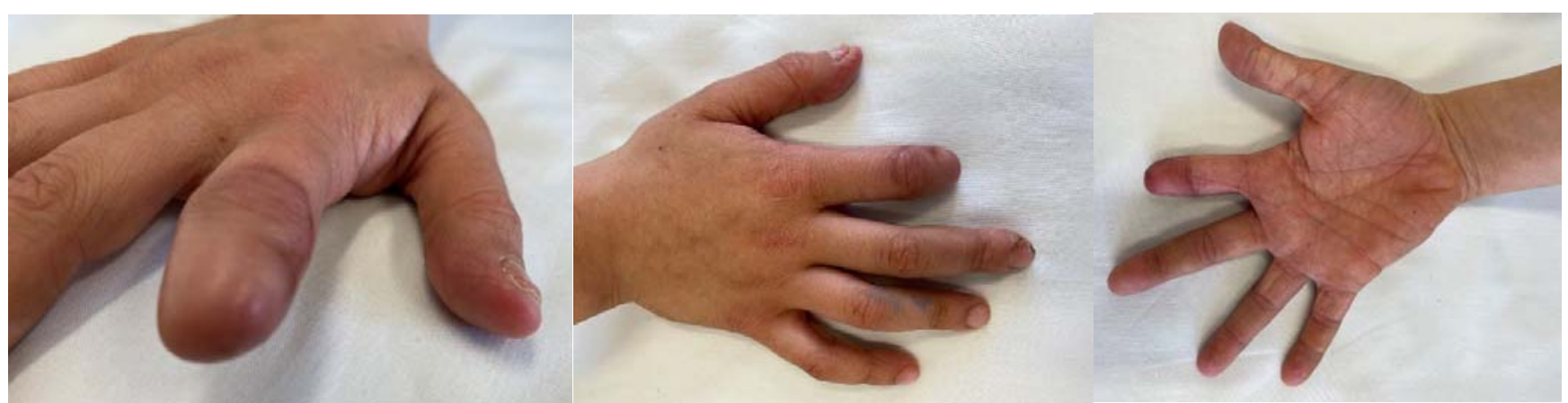

Fig. 5-7. The result after one month from surgical treatment

In order to prevent fires and to ensure operative interventions, the organizers of fireworks with pyrotechnic objects from classes III and IV must notify the local fire service 24 hours before their conduct.

All these safety and accident prevention measures are not enough if the population is not properly informed through various media, such as the press, television, radio or authorized brochures, so that the danger itself can be fully realized.

During the winter holidays and Easter, illegal traders sell pyrotechnic products of dangerous grades without approval or precautions. These products also end up in the hands of unsupervised children who become direct victims of injuries caused by uncontrolled explosions or may cause other indirect victims. 
Studies say that most of the injuries caused by pyrotechnic products and hospitalised, were caused by firecrackers and sparklers [2]. Basically a law cannot totally prevent the population from obtaining and using fireworks. Injuries due to fireworks can result from both legal [6] and illegal ones $[7,8]$. In order to develop safety measures, the type of fireworks causing injuries should be punctiliously studied and a comprehensive approach is necessary [9-14]. Recommendations include parental education and supervision at home during holidays like Easter and Christmas or New Year's Eve, and only attending formally organised fireworks displays [12,15].

Legislation has a significant effect on injury rates. In some states in America, were the law was permissive, injury rate was seven times greater [12]. In Hungary, incidences were reduced following a 'legislative ban on private fireworks displays' [13].

Many studies recommend the introduction of stricter regulations and banning the sale of pyrotechnic objects.
There should also be greater control of sellers and encouraging the population to use only approved fireworks and sites. School education has to be supported and developed [16].

\section{Conclusions}

Fireworks are associated with serious injuries. Hands and fingers are more affected; other body parts affected by firework accidents are the legs and eyes, followed by the head, face, ears and arms.

It is important to know that most of these injuries among pediatric age group can be preventable. Fireworks must not be given to children even in safe public sites.

Legislation must be more severe and the competent authorities must closely monitor its observance both during the festive seasons and throughout the rest of the year. Also parental supervision and school education are also needed to prevent injuries from pyrotechinc devices.

\section{References}

1. Pearsall J,Trumble B, eds. Oxford English reference dictionary. Oxford: Oxford University Press, 1995.

2. Abdulwadud O, Ozanne-Smith J. Injuries associated with fireworks in Victoria: an epidemiological overview. Injury Prevention 1998;4:272-275.

3. https://www.chop.edu/news/health-tip/fireworks-andsparklers-risks-children-are-real. Fireworks and Sparklers: The Risks to Children Are Real. Health Tip of the Week, Jul 02, 2019.

4. Vassilia K, Eleni P, Dimitrios T. Firework-related childhood injuries in Greece: a national problem. Burns: Journal of the International Society for Burn Injuries, 2004, 30(2):151-153.

5. Norma tehnică privind deținerea, prepararea, experimentarea, distrugerea, transportul, depozitarea, mânuirea și folosirea materiilor explozive utilizate în orice alte operațiuni specifice în activitățile deținătorilor, precum şi autorizarea artificierilor și a pirotehniștilor din 30.05.2002.

6. McFarland LV, Harris JR, Kobayashi JM, et al. Risk factors for fireworks-related injury in Washington State. JAMA 1984;251:3251-4.

7. Smith GA, Knapp JF, Barnett TM, et al. The rockets' red glare, the bombs bursting in air: fireworks related injuries to children. Pediatrics 1996;98:1-9.
8. Center for Disease Control and Prevention. Fireworksrelated injuries during the new year period, Naples, 1992-93. MMWR Morb Mortal Wkly Rep 1993;42:201-3.

9. Witsaman RJ, Comstock D, Smith GA. Pediatric fireworks-related injuries in the United States: 19902003. Pediatrics 2006; 118: 296-303.

10. Clarke J, Langley JD. Firework related injury in New Zealand. NZ Med J 1994; 107: 423-425.

11. Berger LR, Kalishman S, Rivara FP. Injuries from fireworks. Pediatrics 1985: 75(5): 877-882.

12. Smith GA, Knapp JF, Barnett TM, Shields BJ. The rockets' red glare, the bombs bursting in air: Fireworksrelated injuries to children. Pediatrics 1996; 98(1): 1-9.

13. Kuhn FC, Morris RC, Witherspoon CD, et al. Serious fireworks-related eye injuries. Ophthalmic Epidemiol 2000; 7(2): 139-148.

14. Committee on Injury and Poison Prevention. Fireworksrelated injuries to children. Pediatrics 2001; 108: 190191.

15. Provinsie Wes-Kaap. Provinsiale Koerant 6347. Chapter 11 - Fireworks. 3 Maart 2006.

16. Sheller JP, Muchardt O, Jonsson B, Mikkelsen MB. Burn injuries caused by fireworks: effect of prophylaxis. Burns 1995; 21(1): 50-53.

\section{Correspondence to:}

Florin-Daniel Enache

Bd. Tomis Nr. 308

Bloc LT3, Scara D, Ap. 46

900407 Constanța

Tel. +4 0723012140

Email: dr.enache@chirurgiecopii.ro 